\title{
MILITARY CONTEXT AND ITS INFLUENCE IN WOMEN'S LANGUAGE
}

\section{EL CONTEXTO MILITAR Y SU INFLUENCIA EN EL LENGUAJE FEMENINO}

WELLINTONG INTRIAGO ALCÍVAR ${ }^{1}$

Recepción: 3 de agosto de 2020

Aceptación: 26 de octubre de 2020

\footnotetext{
${ }^{1}$ Universidad de las Fuerzas Armandas (ESPE). Degree in Applied Linguistics at English Language Teaching. wintriago1980@gmail.com
} 



\title{
MILITARY CONTEXT AND ITS INFLUENCE IN WOMEN'S LANGUAGE
}

\author{
EL CONTEXTO MILITAR Y SU INFLUENCIA EN EL \\ LENGUAJE FEMENINO
}

Wellintong Intriago Alcivar

KEY WORDS: Women's speech, Ecuadorian Army, Linguistic repertoire, Military register

PALABRAS CLAVE: Habla femenino, Ejército Ecuatoriano, Repertorio lingüístico, Registro militar

\section{RESUMEN}

De acuerdo a (Tusón, 2016) existen dos estilos discursivos diferentes: un estilo femenino y un estilo masculino. Ambos estilos han tomado forma debido a las funciones que mujeres y hombres han desempeñado históricamente en la sociedad. No obstante, (Lakoff, 1981) concluye que su aparición entraña un problema de frecuencia más que de presencia o ausencia totales. Esta diferencia es más evidente en campos que se creían exclusivos para los hombres, y es la razón por la cual este artículo busca determinar si una mayor frecuencia de mujeres incursionando a entornos militares influye en el lenguaje femenino, 
por medio de aspectos como: entrenamiento militar, pertenencia, prejuicios, formas vernaculares, entre otros.

Por otra parte, las investigaciones de (Coates 1996 \& Holmes 1995) concluyen que el carácter más cortés del habla femenino se valora positivamente como una habilidad comunicativa, que demuestra sensibilidad hacia las necesidades de imagen del interlocutor. Es así que esta investigación descriptiva, donde se recolectaron datos mediante entrevistas grabadas y encuestas, nos permitirá analizar la utilidad de las habilidades lingüísticas de las mujeres en entornos castrenses ecuatorianos.

Finalmente, esta investigación señala algunos aspectos que podrían ser considerados por las mujeres que a futuro incursionarán en la vida militar, brindándoles pautas útiles que contribuirán a una mejor integración.

\section{ABSTRACT}

According to Tusón (2016), there are two different discursive styles: a female style and a male style. Both of them have been adapted due to the roles that women and men have, historically, played in society. Nevertheless, Lakoff (1981) concludes that this fact happens because of the frequency rather than total presence or absence. This difference is more evident in fields that once were reserved only for men. This is the reason why, this article attempts to determine, whether a higher frequency of women dabbling in military environments influences female language, through aspects, such as: military training, belonging, biases, vernacular forms, among others.
On the other hand, the investigations of Coates (1996) and Holmes (1995) conclude that the more polite character of female speech is positively valued as a communicative ability, which shows sensitivity towards the listener's needs. Thus, this descriptive research, which collected data by means of recorded interviews and surveys. will allow us to analyze the usefulness of women's language skills in Ecuadorian military contexts. Finally, this research highlights some aspects that might be taken into account by women who would like to join the military in the future, providing them with useful guidelines that might contribute to a better mainstreaming. 


\section{INTRODUCTION}

The mainstreaming of women to the Armed Forces in Ecuador started in 1956, with the recruitment of two women, who were meant to work in hospitals and trials as officers. Then in 1974, about 100 women soldiers joined the Army to work as clerks. Nonetheless, this project did not reach a happy ending due to the lack of planning, facilities, and laws that support it. Later, in 1999, the Ecuadorian Army reopened the doors to the first women who took part in a regular course, which lasted 4 years (Troya, 2014).

From that moment on, the numbers of women joining the Army have raised considerably. They have even dabbled in branches like Military Intelligence, Signal Corps, and Artillery; in services like Quarter-masters, Ordnance, and Transportation; as well as, in different affairs like clerks, medical services, musicians, etc. This plan expects that, eventually, women also dabble in Combat branches. (Morales, et al. 2017). Nowadays, more than 600 women are serving the Army, both as officers and as non-commissioned officers, who have the support of laws (Defensa, 2017).

It is worth pointing out that other armies also followed similar processes to recruit women. That is the reason why, a lot of studies have been carried out in order to analyze whether the mainstreaming of women to the Armed Forces is facing rejection by male soldiers, or they both men and women are getting used to working shoulder-to-shoulder. The Colombian Army also recruited women; nevertheless, according to Cuenca (2016), government authorities, the Army and the citizens, have raised their voices against the mainstreaming of women to the Army. This view brings to light the need for analyzing factors that might be considered as the causes of this rejection like physical biology, standards, or military register.

Cuenca (2016) claims the following:

... the military language is used to prepare men mentally to face the war; the way they address their speeches; the interpretation of masculinity, in order to raise male soldiers' ego, is focused on making they feel capable of commanding others while building a strong power notion, because of the fact they are male soldiers (...) On the other hand, to assimilate the military register, women have to learn both formal and vernacular forms, which is commonly used within soldiers (p. 60). 
On the other hand, there is no point in preventing soldiers from speaking the way they are used to, when varieties like military harangues have been so useful, either to raise soldiers' stamina or to test their morale. Regarding harangues, Acelga (2019) shows the undercover role of genders in the military leadership, highlighting such insights as obstacles, that inhibit women from communicating their leadership while empowering men to do so.

In the Ecuadorian Army, harangues are commonly used during military training, in order to provide the needed energy or adrenaline so that soldiers overcome challenging obstacles. However, Acelga's research concludes that women cannot harangue others, since this variety is designed by men, to motivate men. In other words, women are neither capable to motivate themselves nor others, due to the military language's biases.

Opposite to this perception, women have shown they are pretty skillful, as to overcome mainstreaming processes successfully, in a lot of fields. In the linguistic field, these programs are not focused on genders, but on the social migration process into ESL countries, which are known as "immersion". Brown (2000) describes this process as programs where learners attend similar levels classes, sharing the same L1 to achieve proficiency in the SL, which is supported by both: parents and the community.

Even though this is not the same context, similar features seem to match with that of the mainstreaming of women into military language. To illustrate, when women take part in their first military course, they struggle to understand the language used by other soldiers; then, they are supported by the surrounding community - senior soldiers. After this stage, they get used to speaking the symbolic repertoire, which engage them to the military. Men do not skip this process: they also struggle to understand the military language, but as the male community is larger, the adaptation period is shorter. This insight will be confirmed by means of recorded interviews, as well as surveys that were sent to women, who are currently serving the Ecuadorian Army.

In contrast, Rial (2009), cited by Iza (2014), holds that the mainstreaming of women into the Armed Forces should not only be focused on rebuilding military facilities (barracks, bathrooms, etc.) but on rethinking the way in which language is used in certain military ritual and forms. Being that the case, after the mainstreaming of women to the Army; the military register might have been softened, so that women are able to dabble successfully in the military. 
Nonetheless, in other fields, women have vastly proven they cannot only survive but empowered to those contexts throughout an adequate usage of language. More than 15 years ago, Frize suggested that we need to involve male role models who: support progress, build up women credibility, and train everyone on the different women's and men's communication styles and approaches. In other words, we all need to acknowledge the different styles of language, and take the best of both sides in order to reach common goals.

In the same vein, it is clear that women have innate skills to use language smartly; they can accommodate their repertoire in the right context, which is not that easy for men. Tusón (2016), states that elements like: prosody, morphosyntax, lexicon, pragmatic, and suprasegmental features, are just some of the aspects that clearly show the divergence between both styles; nonetheless, this fact does not mean that, neither all men nor all women use the typical features of each group.

Concordantly, Lakoff (2004), cited by Ferreira( 2015), posists that since childhood women are brought up to speak with extreme finesse and politeness, avoiding straight language and any kind of utterances that might sound too cutting or tough. That is the reason why, this article is devoted to discover how women behave in linguistic contexts, which may be considered hostiles, not only to women but also to men.

In this sense, one way of dabbling successfully into these contexts is by showing membership within the community; yet, for women, it is not easy to be accepted into macho communities. Holmes settles that if a community is very hierarchical, for instance, and within each level of the hierarchy, men are more powerful than women. Then, linguistic differences between women's and men's speech may be just one dimension of more extensive differences reflecting the social hierarchy as a whole.

On the other hand, command and control, in the Ecuadorian Army, are neither acquired because of gender nor by social status; indeed, both female and male soldiers are promoted to the superior rank, as long as they meet all the legal requirements and years of service, which in turn, adjudge authority to command subordinates. In other words, the "power", in the Army, has nothing to do with genders, in spite of some men's biases that still remain; but, inasmuch time goes by, these prejudices are getting slighter.

In an attempt to discover whether women's language is fostering their dabbling to the military, some surveys were sent to women, who were currently serving the Army, in order to get 
reliable data. In addition, four women were interviewed to get examples and stories about the usage of language inside the military units. By this investigation, the writers also attempt to draw conclusions about the influence of mili- tary contexts, in the way women speak, while discovering whether the military language gives enough confidence to women, as to become members of this community, that some years ago was exclusive for men.

\section{MATERIALS AND METHODS}

Regarding the descriptive method applied in this investigation, Bernal (2010) holds that such studies: narrate, point out, or identify facts, situations, features, characteristics of aresearch object, or design products, models or prototypes, guides, etc. (p. 133). Consequently, this research is focused on identifying: features, models and prototypes of women's linguistic repertoire, used by them in military environments. In the same context, Bernal (2010) also states that this kind of study is mainly supported on techniques like: surveys, interviews, and observations (p. 122). Concordantly, the instruments used to gather the information from the sample are those named before.

Currently, there are 663 female soldiers serving the Army, up to June, 2020. From this group, neither specialist officers nor NCO's with less than 4 service-years, are considered, since they either work in areas, which are not so close to military, or they are too novice. Hence, the population of this research is $4 \mathrm{fe}$ male courses - 16 officers and 106 NCOs - and the sample is 26 female soldiers. The sample might be seen as unreliable; however, it is significant to highlight that soldiers are serving in a variety of military posts around Ecuador, where there are no more than 6 women soldiers per military unit. As a matter of fact, the validity of this research rests on the trend of the results gotten from the used instruments to gather information.

Hence, to gather information about the way women use language inside the boundaries of a Military Unit, we recorded four conversations, in different contexts. Two interviews were recorded in-situ; and the other two were recorded via zoom. As the interviewer is an NCO, who has worked with them in diverse contexts, confidence is expected when answering the questions; although, not in the same level, due to the professional relationship among them.

After finishing the recordings, the 
interviewer listened to the audios minute by minute, in order to get the right moment, where women set examples on the way they spoke, as well as the expressions related to language aspects, which have already been studied, in other contexts, so that the findings and results collected in military environments are either confirmed or contrasted with those already gotten from prior studies.

Based on the data gotten from the audios, a 12 questions-survey was elaborated by using Google forms. This survey was sent to 22 female soldiers, via Whatsapp, in order to get their responses, which were organized according to the Linker-scale. This research also considers the writer's observations, which provides important inputs related to the linguistic repertoire used by women in military environments, where women have dabbled successfully.

\section{WHAT IS KNOWN ABOUT WOMEN'S SPEECH}

Many linguists have devoted a lot of time to explore and investigate the wonderful world of women's language, in order to provide logical explanations on the causes that produce the choice of a specific linguistic variety. In this respect, Holmes (2013) claims that there are communities, where the language is shared by women and men, but particular linguistic features occur only in women's speech, or only in men's speech. These features are, usually, "small differences in pronunciation or word-shape" (p. 160).

Analyzing the last statement, there is no apparent reason for this phenomenon to happens, since women and men grew together and lived in the same environment. But, beyond this superficial overview, there is more information than one might imagine. Discrimi- nation, social status, functions, biological features, strength, weakness, confidence, purpose, etc. are some of the aspects that force or motivate women to think twice when they speak.

Another key factor, about women language, is that of playing the role of guardian of the society values. Holmes (2013) holds that women are designated the role of modeling correct behaivour in the community. Predictably, following this argument, society expects women to speak more correctly and standardly than men, especially, when they are serving as models for children's speech (p. 168).

Furthermore, Tannen (1995) says that, from childhood, most girls learn that sounding too sure of themselves will make them unpopular with their peers. 
Thus, girls learn to talk in ways which balance their own needs with those of others. That is to say, women learn from very young, how to use linguistic strategies to sound unsure, as well as, to balance the communication. Fisher (2000) also states that test after test and culture after culture, women stand out in the way they build sentences, choose words, and pronounce smooth sounds of the spoken language. Women, in average, express better what they want to say.

Nevertheless, there are contemporary studies that are still focused on aspects that affect the way women speak, for instance: "We contend that in our complex social environment, the construction of self-identity is more problematic for females than for men" (Caldas, 2020). Consequently, more inputis necessary to determine whether views like this still lingers, or fades out, as women dabble in occupational fields, which used to be banned for them not long ago; where, day after day, they are more empowered and more self-confident.

Thus, in this article, we will take a closer look at women's language, so that readers can determine whether the female style remains untoucheable, even under the influence of the military context, or if there are some factors that might change it.

\section{LANGUAGE SPOKEN IN THE MILITARY}

military has always been known as one of the toughest carrers. In this setting, men are meant to show strong stamina to overcome obstacles. After finishing the military training, the bonds that joint them linger for long time as a kind of commitment that feeds soldiers with a vast confidence to speak in military environments, where they use words like: [Comando, body, rancho, terreno, parte, retreta, parada, diana, falto, franco] in formal environments; however, in day-to-day contexts, there is a lexicon that is not included in any military dic- tionary, for instance [arengar, arrastrar, recluta, ficha, muérgano, pulgoso, ñeque, aguanta, pecora, coico, sucho, mi sub...]

The adaptation to this lexicon, is neither easy for women nor for men, since these words are usually heard among comrades' chats or within informal settings, which the cadets or recruits are not familiar with. According to the setting, where a process of communication takes place, the occurrence of vernacular forms might either increase or decrease. To illustrate this fact, in formal meetings, where general officers, officers 
and NCO's attend, military formality prevails, but when talking to closed comrades, vernacular forms stand out.

About 20 years ago, the Military, framed by stereotypes and male lexicon, accepted 8 women, as cadets of a 4-yearscourse. Even though, women possess excellent features to adapt themselves to any field, military setting was not that easy. Anyhow, from that moment on, the number of women joining the Army has increased; and currently, there are 630, serving the Ecuadorian Army, in diverse services and administrative affairs; indeed, during the last years they have dabbled into branches like: Artillery, Military Intelligence. and Signal Corps, where the military language is mainly focused on how to deal with men.

Regarding linguistic registers like: harangues, Suárez, Conejo, \& Panarese (2019) supply valuable input, about the obstacles women have struggled with, when motivating soldiers, due to: the lack of identity, divided opinions about leadership, language exclusion, and so on. This research was carried out in Spain and shed lights to the need of insights about women's reality in the Ecuadorian Military.

In her masters research, Iza (2014) claims "The women's insertion to the Ecuadorian Armed Forces lays on historic background that are outlined by a male tradition supported on authoritarian postures and hierarchy that set men as the only character". Opposite to this view, the writer states that hierarchy has nothing to do with gender. Hierarchy is based on years of service and seniority, which is reinforced by the right language choice, either to show authority when leading soldiers or to create rapport among comrades.

- Military terminoly meaning at the end of the article

\section{FINDINGS AND RESULTS}

\section{FINDINGS (AUDIOS)}

\subsection{Mainstreaming}

- In the minute 00:04:20, interviewee "A" says it was difficult to use military language, but as time goes by, they get used to it, and is not that odd anymore.
- In the minute 00:02:15, interviewee "B" claims that it is not only women but also men who strive to understand the military lexicon at the beginning.

- In the minute 00:00:48, interviewee "C" confirms that it was difficult, at the beginning, because 
she was not able to understand military orders.

- In the minute 00:07:00, interviewee "D" asserts it was quite difficult, especially, when addressing soldiers by ranks or seniority, but after a while, it became easier.

\subsection{Biases}

- In the minute 00:07:10 interviewee "A" states she does not pay too much attention to this issue, because women are able to get familiarized with it.

- In the minute 00:05:10 interviewee "A" says they do not want to be seen as tender soldiers or considered as a breakable point, due to the way they speak.

- In the minute 00:26:47 interviewee "B" admits men are used to stereotyping women, by saying they are not strong enough for military duties.

- In the minute 00:44:05 interviewee "B" claims that some words could not be pronounced by women. She also says military ranks are only designed for men.

- In the minute 00:11:30 interviewee "C" emphasizes men do not treat women as harsh as they do when speaking among them.

- In the minute 00:06:37 interviewee "C" asserts they just adapt words like bodicito or bodicita. She does not pay too much attention to these language biases.

- In the minute 00:18:05 interviewee "D" illustrates this fact, by a phone call, where the speaker addressed her as a male soldier instead.

\subsection{Accommodation}

- In the minute 00:04:52 interviewee "A" acknowledges they accommodate their language repertoire when talking to both senior officers and subordinates.

- In the minute 00:02:38 interviewee "A" says they use politeness to command subordinates, so that they all get along well, with each other.

- In the minute 00:15:40 interviewee "B" says she commands subordinates politely in order to gain their willing collaboration.

- In the minute 00:10:50 interviewee "B" emphasizes that even when she gets along well with others, she reckons her role and the way of addressing each other.

- In the minute 00:02:35 interviewee " $C$ " sets they use formal language when they address chief officers; simple and clear speech when they take over troops.

- In the minute 00:02:35 interviewee "C" emphasizes that the polite lin- 
guistic repertoire is a powerful tool to be obeyed without rejection.

- In the minute 00:04:05 interviewee "D" claims they use politeness because some soldiers - either women or men-find it difficult to be commanded by women.

- In the minute 00:03:26 interviewee "D" holds she uses military expressions to address senior ones, but not to tell off nor to punish subordinates.

\subsection{Membership}

- In the minute 00:01:18 interviewee "A" says they are influenced by the surrounding lexicon; as a result, they feel part of the military.

- In the minute 00:03:26 interviewee "A" claims they feel free to speak because they assume nobody is judging them because of their speech.

- In the minute 00:21:08 interviewee "B" declares they use military lexicon to build rapport, which is fostered by speaking the same language.

- In the minute 00:06:27 interviewee "B" narrates a life passage when she spoke confidently and used the military register to tell the recruits off.

- In the minute 00:02:35 inter- viewee "C" illustrates membership by the creation of words and their use to encourage themselves.

- In the minute 00:07:48 interviewee "D" sets examples of the way soldiers make jokes among themselves to show membership to the military community.

- In the minute 00:05:45 interviewee "D" exemplifies the confidence she feels to tell other soldiers off as well as to give advice to subordinates.

\subsection{Military training}

- In the minute 00:01:22 interviewee "A" says that in military training, they use vernacular forms, and even they speak out and swear words to encourage themselves.

- In the minute 00:27:25 interviewee "B" announces that, in military courses, they have to learn how to support each other by mean of harangues.

- In the minute 00:03:35 interviewee "C" holds that, during military training, soldiers need stamina and strength, which are not gotten with subtle words.

- In the minute 00:19:45 interviewee "D" asserts that, in the training, they hear swear words to make them feel down, but this fact, does not make them give up. 


\subsection{Vernacular forms}

- Interviewee "A" says women use vernacular forms, in their daily routines, but the lexicon is more explicit only when they speak with close comrades.

- Interviewee "B" shows the usage of vernacular forms during the interview, although she avoids using swear words.

- Interviewee "C" holds that vernacular forms are necessary in the military environment, but swear words are not so common among women.

- Interviewee "D" states she uses vernacular forms, but it depends on the context and the person, she addresses to.

- In the minute 00:15:40 interviewee "D" illustrates the effect of vernacular forms, and even swear words on comrades, when feeling down during military training.

\section{FINDINGS - SURVEYS}

Figure 1. Mainstreaming to the military language 1

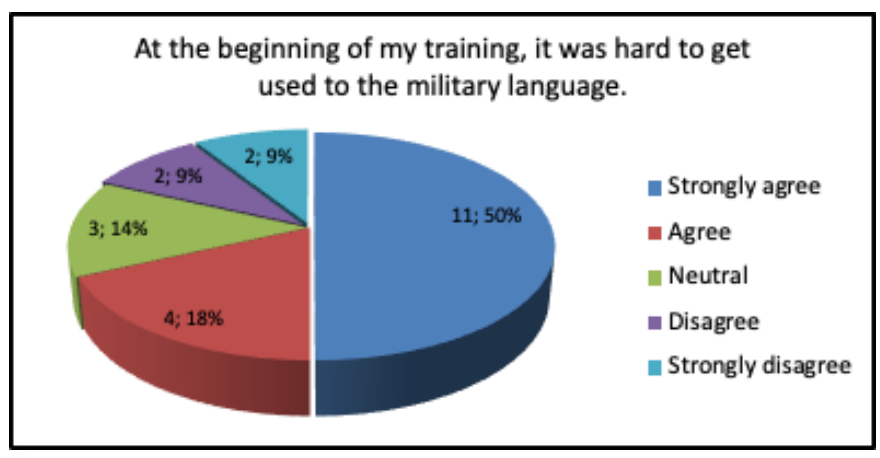

Source: Own elaboration 
Figure 2. Mainstreaming to the military language 2

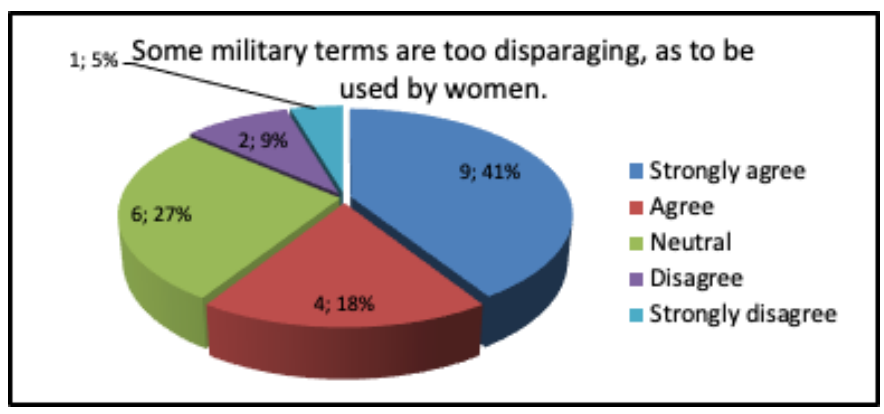

Source: Own elaboration

Figure 3. Military language's biases 1

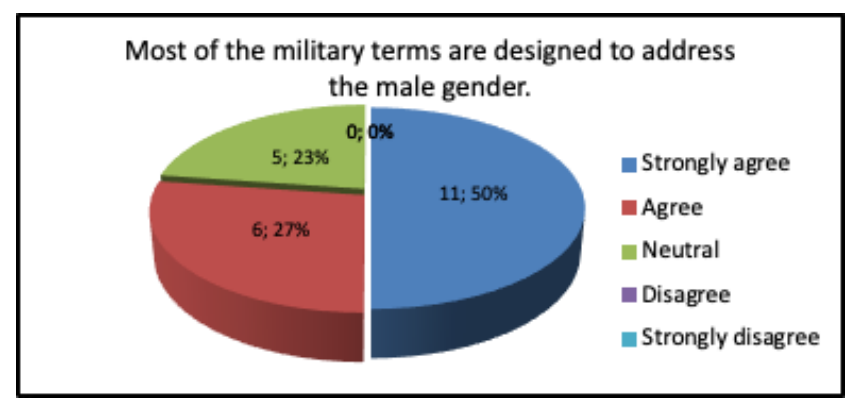

Source: Own elaboration

Figure 4. Military language's biases 2

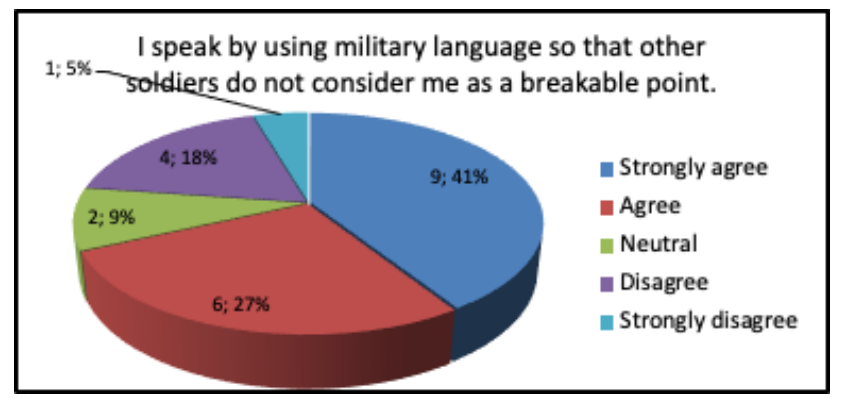

Source: Own elaboration 
Figure 5. Language accommodation 1

Polite language improves the working environments and gets my orders obeyed in a better way.

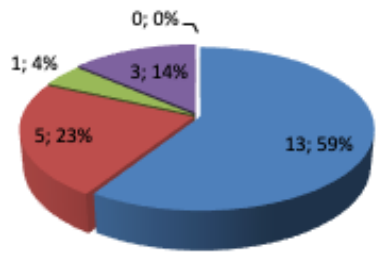
- Strongly agree

- Agree

Neutral

- Disagree

in Strongly disagree

Source: Own elaboration

Figure 6. Language accommodation 2

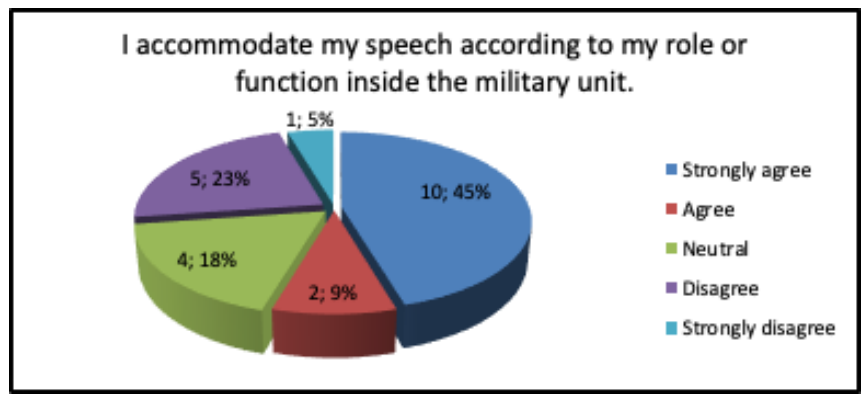

Source: Own elaboration

\section{Figure 7. Membership 1}

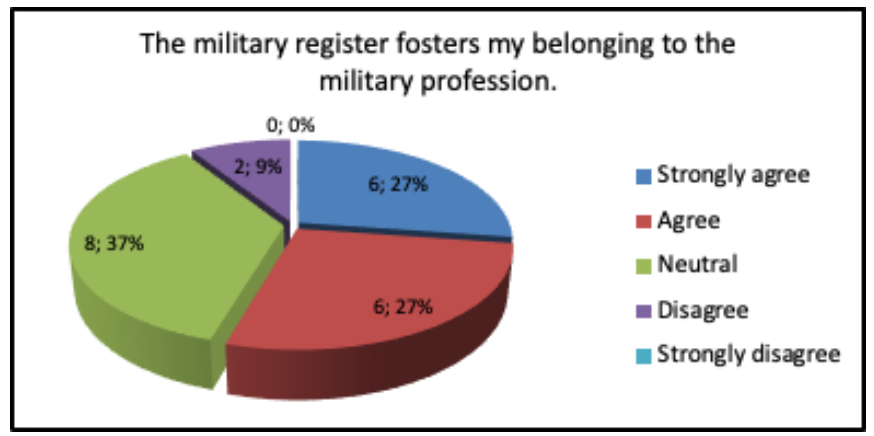

Source: Own elaboration 
Figure 8. Membership 2

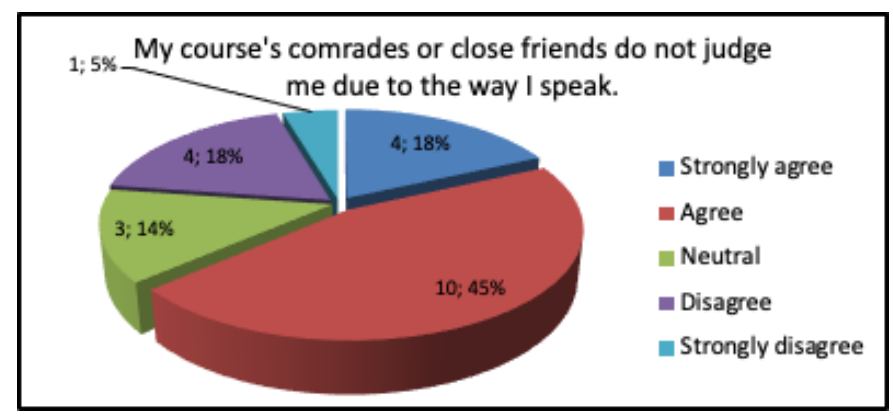

Source: Own elaboration

Figure 9. Military training1

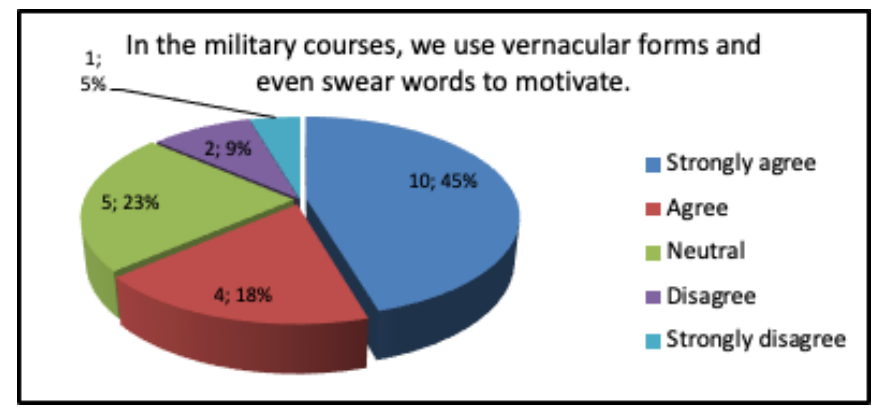

Source: Own elaboration

Figure 10. Military training 2

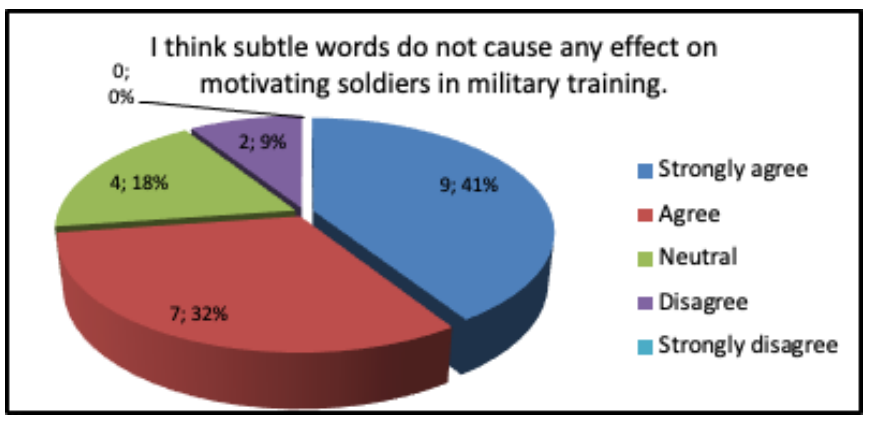

Source: Own elaboration 


\section{Figure 11. Vernacular forms1}

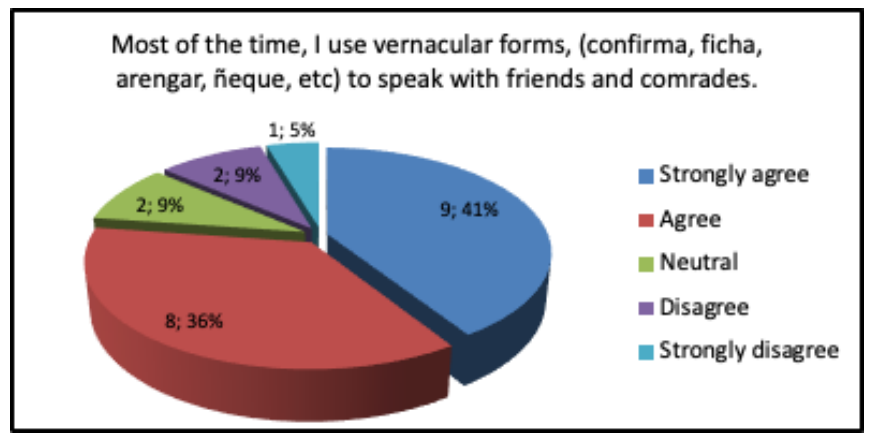

Source: Own elaboration

Figure 12. Vernacular forms 2

\section{I prefer telling off or giving commands to men rather than women.}
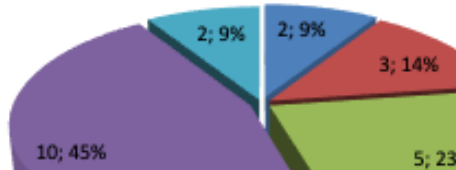

5; $23 \%$

Agree

neutral

E Disagree

- Strongly disagree

\section{FINDINGS - OBSERVATION}

The observation might offer reliable input, either to confirm or to contrast findings and results, gotten from the other investigation tools used to gather data, in this research. It is shown that when they address to another military woman, who is not familiar with them, their speech is polite and respectful, taking care of each word and sentence they use, and adding military formalities, too. On the other hand, it seems they show rejection to obey orders that come from female soldiers.

In additon, when they talk to soldiers - man or women -, who are 
closed to them, the vernacular forms also add some rudeness nuances. However, it is worthwhile to point out that even when it is common for them to use vernacular forms, in military setting, it seems that male soldiers are used to add more swear words to this variety, which is not so common within female soldiers'speech.

\section{RESULTS}

According to the findings that support this research, we compare these occurrences in different environments, as well as, to contrast what has already been stated about women's language, in military settings.

Mainstreming: "Female language is used to talk about complementary aspects while male features are designed to important affairs. Consequently, women take part in social orders, where they learn to live under commands and establish relationships in second level or rank" (Cuenca, 2016). Moreover, Cabeza \& Rodríguez (2018) claim that women take part in almost all the spheres of the public life. Therefore, it is not that odd that women had succesfully dabbled in military.

Taking as reference both insights, it was found that, even though, women struggle with adaptation to military, especially with the terminology related to hierarchy and military commands. After some years, they get used to dealing with this kind of language, because they reckon that if they want to be part of the military, they must acquire military language to build rapport among soldiers. This will allow them to empower of this field.

Bias: Frize (2005) claims that: "One main obstacle to women's retention or participation is that women's contributions and abilities are less valued than men's and women are generally ignored in mainstream history" ( $p$. 4). Furthermore, Ferreira (2015) claims that "The male style is valued in public and formal communication while the female's is appropriated for intimal, familiar and informal affairs" (p. 5). In the military context Cuenca (2016) posits that "Men were angry since from their view that is not a setting for women, while women's rejection was produces because of the hostile treatment that did not let them to take part when making decisions, do not even in administrative affairs" (p. 57).

Opposite to these biases, both the interviews and graphic 2, show that the military language is focused on men; occasionally women were treated as men. Furthermore, they claim that there are words that sound too rude as to be 
pronounced by women. Nevertheless, they pointed out, that these biases are getting slighter, as women are promoted to higher ranks, since in the Army, the tasks are assigned based on ranks and seniority, instead of taking into account the genders.

Accommodation: Tannen (1995) holds that "As a form of social behavior, language also negotiates relationships. Through ways of speaking, we signal and create - the relative status of speakers and their level of rapport" (p. 140). Furthermore Liu, et al (2017) state that "Language is an important factor in the creation and reinforcement of an individual's identity, particularly in the context of in-group and out-group interactions" (p. 86).

Regarding this issue, $54 \%$ of the results show that the accommodation is based on the role and function; as a matter of fact, they build a better working environment by using polite devices to accommodate their linguistic repertoire. The interviews show similar results, except for the input provided by interviewee " $\mathrm{D}$ ", who states that it is difficult for men to be commanded by a female soldier.

Membership: Lakoff (2004), cited by Ferreira (2015), stated that women's language might turn into an obstacle to reach professional success, especially to be promoted to positions with more responsibilities, where leadership skills are required. On the other hand,a research carried out by Ferreira (2015), values positively women's language as a communicative skill that shows sensibility towards the listener.

Contrasting Lakoff's view, $63 \%$ of the results establish women do not feel stereotyped by the way they speak; $54 \%$ of the results also acknowledge that by mean of military register they enhance their membership to the Army. Besides, most of the interviewees hold that as soldiers come up with new terms and make jokes among them, they learn to speak the same language, which reinforces their membership to the Army. With regard to Ferreira's perception, in military settings, it is likely to see women showing sensibility in a certain way ;nevertheless, what they do want to demonstrate is solidarity and also membership to the Army.

Military training: In the military, sooner or later soldiers will have to command subordinates; then, they need to acquire leadership skills that allow them to take over. Most of these skills are learnt during the military training by mean of harangues, which either motivate them 
or teste their morale. Concerning this issue, the results gotten from the research carried out by Suarez (2019), embraces the vision that "concepts related to gender in the military harangues might be an obstacle to carry out the communication of female leadership" (p. 289).

Divergentto this view, $63 \%$ of the results, regarding this issue assert that, within military courses, the military jargon is commonly used by both women and men; while $73 \%$ of the answers, related to the way of motivating soldiers, show that tender words are not useful to provide, neither strength nor energy, since they need to overcome challenges. That is, women admit that, during the military training, their level of confidence rise as to harangue themselves, which let them express their leadership on subordinates.

Vernacular forms: Coupland (2016) considers vernacularisation as a sociolinguistic change running counter to the better established process of linguistic standardization. In the same context, Holmes J. ( 2013) states that the vernacular is the variety used for communication at home and with close friends. It is the language of solidarity between people from the same ethnic group. Once again,
Holmes concludes that women tend to use more of the standard forms than men do, while men use more of the vernacular forms than women do.

In the military, vernacular forms build rapport and show that female soldiers, carefully, integrate to the military team, which might enable them to use as many vernacular forms as men, when talking to comrades or close friends.

This statement is based on the $77 \%$ affirmative answers gotten from the question related to this topic. Another notable fact, is the result gotten from the last question, which illustrate that women are able to either command or to tell soldiers off without paying too much attention to genders.

Likewise, the interviews illustrate that women acknowledge the power of vernacular forms either in military training, where sometimes they include some swear words, just to recharge a low morale, or in the dayto-day routine. They also recognize the usage of this variety, both: within comrades and with those who they get along pretty well, since in other context, they know how to manage it, in order to get the best result from the communication process. 


\section{CONCLUSIONS}

According to the findings, it is possible to draw the conclusion that military lexicon is not focused on women; however, female soldiers are not concerned about this issue, since they feel part of the military team. Indeed, the more female soldiers joint the Army, the fewer biases remain. It is worthwhile to acknowledge that in the early stages of the military training, both men and women find it difficult to get used to military lexicon; nevertheless, this period lasts longer for women than for men, since male soldiers' community is larger.

As in any other context, women have fully demonstrated they are skillful enough as to deal with the language accommodation in military contexts; their expertise to use the right linguistic repertoire has let them be obeyed without rejection, as well as, to built better working environments. In fact, their linguistic ability is one of the most powerful devices, they use to avoid biases and validate their membership to the military.

As far as the military training is concerned, it creates bonds within soldiers that usually last forever. During this tough period, soldiers get used to hear- ing harangues, vernacular forms, and even some swear words, which allow them to remain standing until the end of the training. It seems that, as more women soldiers join the Army, the less biases reamain. In fact, some words are used to named, both: male or female soldiers; nevertheless, there are stills few ranks that are not commonly used for women, since just very few of them have been promoted to those ranks, but as time goes by and more women join the Army, these features are fated to dissapear, since women have successfully dabbled in the military.

Finally, it is worthy to suggest that the results gotten from this research might be supper useful for those women who would like to join the Military, since they would know how to use the military register, as well as, the way soldiers deal with language in advance, which would end up in a less complicated adaptation to the Army. This study also opens the doors to other researchers who would like to carry out new studies, by focusing on two groups of female soldiers: officers and NCO's, since both groups have different background, social status and responsibilities inside the Army. 


\section{DEFINITIONS}

Recluta: Any soldier who is not diligent or makes mistakes when performing his/her tasks sometimes due to the short time of service in the military.

Comando: A voice that is often used to call or greet soldiers in some military units even if they are not part of Special Forces.

Body: The soldier who is by your side, the one who a soldier can lean on because he/she is always there to motive her/him.

Rancho: The soldiers' meal and the place where the food is prepared and served. It is even the commission headed by an officer.

Terreno: Military training where all the branches and services carry out missions.

01: The chief officer of a military unit, or the commander of a military course.

Parada: Military duty where soldiers have to take care of the assigned place.

Arrastar: To tell soldiers off either to motivate or to test their morale. Sometimes, this term also stand for the physical exercises that soldiers are due to do due to any failure.

Ficha: A soldier who finds it difficult to obey military orders. This soldier is also pretty lazy and sometimes does not pay attention to his/her responsibilities.

Neque: The stamina inside each soldier that let them go on beyond their limits.

Coico/Coshco: A private soldier who is accomplishing the military commitment.

Civil: Soldiers that do not know how to perform a military task. They are lack formal military instruction and speak different from the military register.

Corta pelo: It is the helicopter equipped to take soldiers from the unit to another place.

Confirma: Expression used among comrades to ask either how they are doing or whether they have accomplished a duty.

Hacha: The punishment that a soldier is due to accomplish after doing something wrong. It is also used to refer to soldiers who punish subordinates regularly.

Más: Word used to refer soldiers with higher ranks either by seniority or years of service.

Menos: It is opposite to "más".

Pécora: Similar to "Ficha" but a little bit more impolite. By using this expression, soldiers are likely to express negative nuances.

Mi sub: Shortform used to refer to sergeants or sub-officers. 
Sucho: Short form used to refer soldiers who are pretty weak as to carry to Second Lieutenants.

his/her individual equipment, ammuni-

Madre: A soldier who is tender as tion and rifle.

to punish another soldier. It also refers to 


\section{REFERENCES}

Bernal, César (2010). Metodología de la Investigación: Tercera edición. Bogotá, Colombia: Pearson.

Brown, Douglas (2000). Teaching by Principles: An Interactive Approach to Language pedagogy. California: Longman.

Cabeza, María del Carmen \& Rodríguez, Susana (2018). Lenguaje excluyente y género. Actas do XIII Congreso Internacional de Lingüística Xeral, 146-153.

Caldas, Carmen (2020). Innovations and Challenges: Women, Language and Sexism. New York \& London: Routledge.

Coates, Jennifer (1996). Women talk: Conversation between women friends . Oxford: Blackwell.

Coupland, Nikolas (2016, September 23). Labov, vernacularity and sociolinguistic change. Journal of Sociolinguistic, 409-430.

Cuenca, Yurley (2016, March 12). La participación de algunas mujeres en el Ejército Nacional de Colombia: Universidad del Tolima. Retrieved June 7, 2020, from Research Gate: https://www.researchgate.net/ publication/321190229_La_participacion_de_algunas_mujeres_ en_el_Ejercito_Nacional_de_Colombia
Defensa: Cartilla de Género de las Fuerzas Armadas (2017, March). Retrieved from: Defensa. https://www.defensa.gob.ec/wp-content/uploads/downloads/2017/03/cartilla-genero-2017-marzo.pdf

Ferreira, Virginia (2015, January 28). El lenguaje y el lugar de la mujer: sociolingüistica feminista $y$ valoración social del habla femenina. Retrieved June 3, 2020, from Research Gate: https:// www.researchgate.net/publication/283614967_El_lenguaje_y_ el_lugar_de_la_mujer_sociolinguistica_feminista_y_valoracion_ social_del_habla_femenina

Fisher, Helen. (2000). El primer sexo. Las capacidades innatas de las mujeres y cómo están cambiando el mundo. Madrid: Taurus.

Frize, Monique (2005, June). Women in Leadership: Value of Women's Contributions in Science, Engineering, and Technology. (C. Morrel, \& J. Sanders, Eds.) Proceedings of the international symposium on Women and ICT: creating global transformation, 4-6.

Holmes, Janet (2013). An Introduction to Sociolinguistics - Fourth edition. London and New York: Routledge Taylor \& Francis Group. 
Holmes, Jannet (1995). Women, men and politeness. Londres: Longman.

Iza, Lyneth (2014, March 16). La inserción de las mujeres en las Fuerzas Armadas Ecuatorianas, Tesis de Maestría. Retrieved June 5, 2020, from Instituto de Altos Estudios Nacionales: Biblioteca José Moncada: http://repositorio.iaen.edu. ec/handle/24000/4007

Lakoff, Robin (1981). El lenguaje y el lugar de la mujer. Barcelona: Ricou.

Lakoff, Robin (2004). Language and woman's place: Text and commentaries (Vol. 3. Oxford: Oxford University Press.

Liu, Amy; Shair-Rosenfield Sarah; Vance, Lindsey \& Csata Zsombor. (2017, November 20). Linguistic Origins of Gender Equality and Women's Rights. Retrieved June 27, 2020, from Sage Journals: https://journals.sagepub.com/ doi/10.1177/0891243217741428

Morales, Ximena; Barba, Rosanna; González, Carlos; Zapata, Juan; Noroña, Diego (2017). Mujeres en las Fuerzas Armadas: El caso del Ejército Ecuatoriano. Revista de
Ciencias de Seguridad y Defensa, 125-131.

Rial Juan (2009). La mujer en las Fuerzas Armadas y Policía en América Latina: una aproximación de género a las operaciones de paz. Buenos Aires: Resdal.

Serra, Acelga (2019) Comunicación, género y educación: Representaciones y (de) construccciones (pp. 286-289). Madrid: Dykinson S.L.

Suárez, Juan Carlos; Conejo, Segio Marín \& Panarese, Paola. (2019, March 26). Re-velando el Papel Encubierto del Género en el Lenguaje del Liderazgo Militar. Comunicación, género y educación. Representaciones y (de)construcciones, 286-289.

Tannen, Deborah (1995). The Power of Talk: Who gets Heard and Why. Harvard Bussiness Review, 139 148.

Troya, María Jose (2014). Inclusión: La vida militar es el reflejo de la sociedad civil. Defensa , 28-30.

Tusón, Amparo (2016). Languaje, interacción y diferencia sexual. Enunciación , 138-151. 


\section{KEY LINKS}

\begin{tabular}{|c|c|}
\hline $\begin{array}{l}\text { Interviews } \\
\text { transcript: }\end{array}$ & https://drive.google.com/file/d/12LW7tVxN5sTHh4NHTiSN95KiRXi6fojj/view?usp=sharing \\
\hline Survey form: & https://docs.google.com/forms/d/1rM7dETxsoWQ3NRY_DvglcMXuiuKenoBuUpddHil5lqU/edit?usp=sharing \\
\hline Survey results: & https://drive.google.com/file/d/101iC8kn31eugEz_vPMt1YJPhFIV5t-7T/view?usp=sharing \\
\hline Interviewee A: & https://drive.google.com/file/d/1C79ipGs7z8yzP4bfP_g073UZ3_yCtll6/view?usp=sharing \\
\hline Interviewee B: & https://drive.google.com/file/d/1I-mGj3s3_5A2SBzaFuWjMIXebg4uYfHv/view?usp=sharing \\
\hline Interviewee C: & https://drive.google.com/file/d/1wh3_gQ5XRwDi7ftx/mbmX8Q3xk6YmPmh/view?usp=sharing \\
\hline 7torvinum & CLIVICV \\
\hline
\end{tabular}

